\title{
Documenting the History of Slavery on Film in Kayes, Mali
}

\author{
Marie Rodet \\ soAs, University of London \\ mr28@soas.ac.uk
}

\begin{abstract}
In 2010 I filmed descendants of formerly enslaved populations in Kayes narrating the history of their ancestors and the realities of internal slavery in West Africa. The result was a 23-minute documentary film entitled "The Diambourou: Slavery and Emancipation in Kayes-Mali," which was released in 2014. The film was as much responding to specific historiographical questions in the field as a tool of research action to raise awareness among younger generations and to fight legacies of social discrimination today. With the exactions perpetuated against descendants of formerly enslaved populations in the Kayes region since 2018, the film, via its access-free online version, has experienced a second life as an anti-slavery activist medium, helping to bridge the gap between endogenous historical fighting against slavery and contemporary anti-slavery activism in the Soninke diaspora.
\end{abstract}

\section{Keywords}

slavery - memory - public history - Mali - documentary film - screening - research action - anti-slavery activism

In her book, Relating Narratives: Storytelling and Selfhood, Cavarero highlights the complex and powerful relations that narratives can create: "I tell you my story in order to make you tell it to me."1 In 2010 I filmed and interviewed with

1 Adriana Cavarero, Relating Narratives: Storytelling and Selfhood (London: Psychology Press: 2000), 62. 
the support of Fanny Challier the descendants of formerly enslaved populations in the Kayes region (Mali) for a month. Les Diambourou; Esclavage et emancipation à Kayes - Mali was released in $2014 .^{2}$ By accepting to be filmed retelling their history and the unique life story of their ancestors, the Diambourou immediately understood that the documentary could be a powerful tool and vehicle for history and memory transmission in their communities and beyond, helping their stories to be told for the first time beyond the boundaries of their own communities, and to continue to be told once they had passed away. The making of this film thus became an extension of their and my own historian's crafts, the possibility of making public history of internal slavery that had never been talked about in the public sphere in Mali until then. The power of film became even more clear to the communities in 2017 when the film was first screened in the villages where it had been originally filmed seven years earlier. ${ }^{3}$ Already by then, a large number of the film's protagonists had passed away and it was emotional for some of the villagers to see their now deceased relatives and community elders on film. Today, 90 per cent of the film's protagonists are gone, and this very fact alone makes the film even more of a unique audio-visual trace of community history on slavery and emancipation for communities which were never given any social and political legitimate space to tell such history. ${ }^{4}$ Yet the film did not just illustrate previous research or recorded and archived disappearing traces, but had an epistemological ambition as it made visible what had remained inaudible. ${ }^{5}$ In this context, both the process of filming and the production of a film appeared urgent and consequential. The film was thus as much a historical knowledge production responding to specific historiographical questions in the field, as well as research action to raise awareness on this neglected aspect of Malian history. With the recent uproar of violence against descendants of formerly enslaved populations in the Kayes

2 The film project and the research to support it were conducted with the generous financial support of the Austrian FWF program Hertha Firnberg, the Vienna International Development Center (VIDC), the Theodor Körner Fonds zur Förderung von Wissenschaft und Kunst, and SOAS.

3 The screening tour was made possible through the support of the Impact Fund at soAs, University of London, the Swiss Embassy and the Cinéma numérique ambulant in Mali. A second series of screenings were organised in Kayes schools in 2018 with again the support of the Impact Fund at soAs.

4 Marie Rodet, "Mémoires de l' esclavage dans la région de Kayes: Histoire d'une disparition," Cahiers d'Études Africaines 197 (2010): 263-291.

5 Marina Rougeon, "Introduction: Des films pour la recherche sur les esclavages et leurs héritages", in Marina Rougeon and Patrick Deshayes, eds., Montrer les esclavages et leurs héritages. Films et regards de chercheurs (Lyon: PUL, 2016), 14. 
region, the film has experienced a second life as an anti-slavery activist medium helping to bridge the gap between endogenous historical fighting against slavery and contemporary anti-slavery activism in the Soninke diaspora. The ubiquitous power of film increased by social media and the web has thus extended far beyond the communities directly involved in the film. To date, since December 2017 when the film has been uploaded and made free of access on the web, it has been viewed in more than 27 countries. Most viewers were from the Diaspora (France, Spain) and in Mali. ${ }^{6}$

In the first part of this article I will discuss my editing choices to explain why and how the film was always conceived as a possible tool for public history on internal slavery in West Africa, but also how it attempts to respond to historiographical debates on slavery in the Sahel. It is thus fully part of my own research agenda. In the second part I will present the reactions of the audiences in the Kayes region to the series of screenings I have organised there since 2017 with the support of a number of institutions and how it has further informed my research. I will finish with a few comments on the film's afterlife as a powerful anti-slavery tool.

\section{1 \\ The Historian as Filmmaker: Why Make a Documentary Film on Slavery in Western Mali?}

My research for the past ten years has been concerned with the history of slavery and emancipation in the Kayes region (1890-1940). West Africa experienced extensive warfare and enslavement in the second half of the nineteenth century. Populations were scattered along the main slave trade routes in the Western Sudan. My research and film explore the oral histories of those scattered communities of enslaved populations in the region of Kayes and how once freed they managed to form independent communities still known nowadays for some of them as the Diambourou.

As this special issue demonstrates, over the last decade, a growing number of scholars have directed documentary films on slavery in order to provide the public with a multidimensional view of the history of slavery and its legacies.

6 From $02 / 12 / 2017$ to 10/o1/2020 there have been 2,959 views in France, 488 in Spain and 397 in Mali according to Vimeo Analytics. Accessed 11 January 2020. The large numbers of viewers in France and Spain can be explained by the importance of the Malian (and Soninke) Diaspora in each of those countries. On Malian migration to Spain, see Annalisa Maitilasso, "Prêts à partir'. Histoires de mobilité transnationale en temps de crise: le cas malien." (Sociology, EHESS, 2017). 
It is also part of a rather recent move in the slavery scholarship of the past 10 years to attempt to retrieve voices of the enslaved and their descendants, not that these populations could not speak or did not have their own history to tell. Yet, as demonstrated elsewhere, it had rather been an issue of who had been listening to what. ${ }^{7}$ The film was thus meant to demonstrate by itself that the issue was not that the formerly enslaved populations and their descendants were unable to tell their history, but that those memories had not been given the space to be expressed in the official public sphere. The film was thus carving the necessary space from which they could speak.

Klein's 1989 article was the first methodological study to approach directly the complex topic of memories of slavery in the Sahel. ${ }^{8}$ While Klein remained rather skeptical on the possibilities of retrieving such memories from the formerly enslaved populations and their descendants, his article offered nonetheless a strategic point of departure for future research to which my film and research are indebted. Actually, the debate on whether enslaved populations had been able to overcome slavery on their own terms and whether those communities could tell their own history of slavery, has never been closed since then. ${ }^{9}$

After having collected more than 150 testimonies about the history of slavery by descendants of formerly enslaved populations in Kayes from 2008 to 2009, using film to respond to the above-mentioned debate soon appeared the obvious strategic tool, especially as colleagues in the field had, on several occasions, showed skepticism in my findings while I presented research in the usual academic form of conference papers. My case study was an exception that confirmed the rule: that is, that slavery in the Sahel had never truly ended. By multiplying the audio-visual interviews in a large number of communities in the Kayes region whose historiography had long denied the possibility for enslaved populations to truly liberate themselves, I meant to let the descendants of the formerly enslaved populations tell by themselves a revisionist and powerful history of the extraordinary human ability to survive slavery directly to the camera before the last generation of those holding this historical knowledge passed away. Their voices had never been heard outside their communities and

7 Marie Rodet, "Listening to the History of Those Who Don't Forget," History in Africa 40 (2013): 28.

8 Martin A. Klein, "Studying the History of those Who Would Rather Forget: Oral History and the Experience of Slavery," History in Africa, 16 (1989): 209-217.

9 See Benedetta Rossi, "Without History? Interrogating Slave Memories in Ader (Niger)", in Alice Bellagamba, Sandra Greene, Martin A. Klein, eds., African Voices on Slavery and the Slave Trade (Cambridge and New York: CUP, 2013), 536-554. 
obviously had never been recorded through film. My main concern in putting these histories on film was thus to make the audience grasp the complexities and multiplicities of histories of slavery in the Kayes region and understand that there was not just one unique history of enslavement and emancipation. This is why I chose to use a large range of interviews in the film with multiple interlocutors, to demonstrate that the history was not exceptional but a shared experience among various communities which later became, for some of them, known as the Diambourou communities.

Above all, it was an effort to reintegrate these neglected memories into the official regional and national public history of Mali by documenting histories of resistance and the struggles for equality which Malians, especially the younger generations, could identify with and thus feel proud of. Since 2017, it has thus been screened on several occasions in schools in Kayes. The short video format of 23 minutes meant it could be screened easily at international academic conferences in Europe, the Americas and Africa. The international dimension of the film then extended beyond the international academic circles as soon as it was made free access online. ${ }^{10}$ Since 2017 the film has been viewed online 4,640 times. ${ }^{11}$

Another motive behind making the film was to preserve memories. Those video-recorded interviews were meant to help build an audio-visual archive of this history. The final result, the 23-minute film, is certainly not raw on primary material as it was edited and conveys specific narratives that are my personal reinterpretation of those told memories. I made the choice to not appear on screen myself, to avoid a voice-over and excessive textual explanations. This way, the film aimed to give priority to the voices of the descendants of formerly enslaved populations and their community history as told by themselves. I certainly did not have the filmmaker's skills to play on light and sound to render specific effects and highlight some aspects rather than others, but I did choose from the outset mid shots as camera angle for the interviews to emphasize the focus on the interviewees and the importance of their speech.

In the same perspective, my own objective for the audience was not to make them understand every detail of the film, but simply to create a space for them to listen to the discourses. The result is certainly dense in information, especially for non-informed audiences, but by doing so it also attempts to convey the complexity of the questions raised and of the research undertaken.

\footnotetext{
10 The film can be accessed online here: https://vimeo.com/245704289 (English version); https://vimeo.com/245704895 (French version).

11 Vimeo Analytics. Accessed 10/o1/202O.
} 
Central to the film was how to convey the performance of historical memory and local understandings of personal origins and heritage beyond the usual scholarly silences? Again, at the risk of the film appearing somehow repetitive, I chose in the editing process to multiply the interviews in which the protagonists could explain where their ancestors came from and what they may have kept and transmitted from their region of origin. Indeed, the cultural dimension of diasporas, African cultural retention through music and religion in particular, has long been observed in the Atlantic world, but it has received only scant attention within the context of emancipated slave communities in West Africa. ${ }^{12}$ Music as a trigger of emotions emerged during the filmmaking as a powerful medium to convey the trauma of enslavement and the extraordinary embodied resilience against the slave condition to the screen. ${ }^{13}$ When I asked whether their parents / grandparents expressed nostalgia for their region of origin, my informants often came up with stories linked to missing the music of their region of origin. Original cultural practices may not have always been transmitted or may have changed and been adapted in the new environment throughout time, but nostalgia and emotions associated with traumatic history were nonetheless, even when truncated, transmitted. The theme of family separation was also part of those traumatic memories.

I was also interested in exploring the concept of memoryscapes through film. Film is indeed a more effective way to convey the physicality of memories than a monograph. By filming landscapes, villages, caves and hills, the idea was to highlight the role of place and its memory testifying to the resilient strategies to carve belonging in an often-hostile environment, in striking contrast with usual histories of forced displacement and loss of memories of origins. The Diambourou communities in Kayes founded specific spaces of belonging, constituting today memoryscapes of the history of slavery in West Africa. ${ }^{14}$

The French may have officially abolished slavery in 1905, but emancipation in Kayes was nonetheless a long process which continued throughout the

12 For example, Melville Herskovits, whose most famous book The Myth of the Negro Past, was published in 1941, argued that although African enslaved populations could not have brought intact social, political and religious institutions to the Americas, they were able to maintain aspects of their cultural backgrounds. These were evidence of resilient personhood and a form of resistance to slavery. Melville J. Herskovits, The Myth of the Negro Past (New York: Harper Brothers, 1941).

13 Benjamin N. Lawrance, “'To Know Where You Come from; That Is Divine': Three New Documentary Films on the African Slave Experience," Slavery \& Abolition, $36: 4$ (2015): 738-746.

14 Marie Rodet, "Escaping slavery and building diasporic communities in French Soudan and Senegal, ca. 1880-1940," International Journal of African Historical Studies 48 (2) (2015): 209-237. 
twentieth century and which beyond the colonial abolition, was not actively facilitated by the authorities. The film is thus an attempt to demonstrate the reappropriation of this history by the communities themselves as interlocutors in the film construct their own narratives of resilience and resistance against slavery. As highlighted by Araujo, it is Doro Traoré, head of the Bangassi-Liberté neighborhood, who subverts the official colonial history by stating: "Liberty, Fraternity, Equality! This is us!" In this way he insists that formerly enslaved populations obtained equality through liberating themselves. ${ }^{15}$ He certainly said that the French abolished slavery but it remained rather anecdotal in his narrative: what matters here was that they were the ones who rebelled against slavery and took their destinies in their own hands.

Whereas slavery is often considered a taboo topic in West African societies, the numerous testimonies collected in the film show paradoxically a liberated speech on the subject by the people who Klein assumed "would rather forget." I did not address in the film specifically the way I conducted the research. As a first-time filmmaker I was unsure how to technically convey those aspects in the film. Even today I am not sure why exactly the investigation worked so well when I conducted the interviews in 2008-2010. It was probably a unique combination of factors: the timing coincided with almost ten years of decentralization and through it full accession and participation of those villages to the democratization process; an extraordinary research assistant, Sounkarou Diouara, with deep social and relational skills and knowledge; my valued status as a foreigner who had travelled all this way to know those communities' specific history; and luck. We also chose very light-weight audio-visual equipment which was easy to set up and not intimidating for the interviewees, so that the protagonists very quickly forgot about the camera's presence. Yet, I do not think I could access so easily those voices today. First, as already mentioned: ten years after making this film, 9o per cent of the film protagonists have unfortunately passed away. Second, the highly degraded security, political, social and economic situation in Mali today, coupled in Kayes with heightened violence exercised by the historical ruling class against the descendants of formerly enslaved population, has put much more pressure on many of those communities and beyond, which makes conducting research in Mali generally increasingly difficult at the moment.

While conducting research in these circumstances is certainly not ideal, it is precisely because the general situation in Mali is unfortunately deteriorating

15 Ana Lucia Araujo, "The Diambourou: slavery and emancipation in Kayes—Mali [DVD]," Slavery \& Abolition, 36:2(2015): 406-408. 
that putting research on film is so necessary now, as a tool of empowerment for populations at risk of becoming more vulnerable.

\section{A Film to Fight against Discrimination in Kayes and Beyond}

As already mentioned, the history of internal slavery is still a taboo subject in West Africa today and the "ideology of slavery" remains pervasive. ${ }^{16}$ Despite this taboo, my research in Mali on the subject for the past ten years has shown that there is demand from local communities to know and understand better this complicated past. The screening of the Diambourou in the Kayes region was thus not just about restitution but was also part of a larger research action plan to redress the lack of awareness of the history of internal slavery in Mali, and the subsequent and enduring discrimination against descendants of formerly enslaved populations in Mali, and West Africa, today. The screening in Mali of Les Diambourou followed by discussions and debates around human rights, citizenship and social justice aimed:1) to put in the spotlight populations who have long been marginalized in Mali because of their status as decendants of formerly enslaved populations, although those communities should be proud of the struggle their ancestors went through to secure their freedom;17 2 ) to raise awareness among young generations about the importance of fighting against all forms of discrimination and exploitation, including modern slavery.

Postcolonial Mali has never criminalized slavery, despite the numerous advocacy campaigns conducted by Malian human rights and anti-slavery organizations such as TEMEDT, and more recently Ganbanaaxu, a transnational Soninke diaspora organization based in France particularly involved in the "Kayes slavery crisis." 18 Mali has certainly signed up to the major international conventions banning slavery (including the UN International Declaration on Human Rights), and passed a law criminalizing international trafficking in 2005. But in today's security situation in Mali the passing of a criminalizing

16 Eric K. Hahonou \& Lotte Pelckmans, "West African Antislavery Movements: Citizenship Struggles and the Legacies of Slavery," Stichproben-Wiener Zeitschrift für kritische Afrikastudien, 2O(2011): 141-162; Eric K. Hahonou \& Baz Lecocq, "Introduction: Exploring PostSlavery in Contemporary Africa," International Journal of African Historical Studies, 48(2) (2015): 181-192.

17 For example social and economic marginalisation is often linked to restricted access to land tenure, employment, education; discrimination in access to political offices; ban on exogamic marriages.

18 Mauritania has passed several criminalising laws since the 1980s, and Niger adopted one in 2003. Implementation remains however difficult. 
slavery law (the project was ready to be discussed and adopted in parliament in 2016) has been time and again subsumed by other time critical agendas, as well as a general amnesia and fraught political environment which display an inability and/or unwillingness to understand contemporary manifestations of slavery.

Yet it has been established in a number of reports by organizations such as Anti-Slavery International that victims of descent-based slavery are amongst the most vulnerable to economic uncertainties. ${ }^{19}$ In such crisis situations as the one prevailing in Mali today, working with those populations is thus an urgent development issue. When it comes to descent-based slavery, Mali is mostly known for such issues among nomadic Tuareg and Fulani communities in Central and Northern Mali. ${ }^{20}$ However, descent-based slavery and its legacies continue to prevail in most communities of Mali. Kayes, as other regions in South Mali, was a major transit zone of slave caravans in the nineteenth century. As the film Les Diambourou shows, the region has experienced waves of emancipation since the official colonial abolition of 1905, yet populations considered of "slave descent" are still discriminated against and stigmatized in Mali, with some even victims of severe actions. ${ }^{21}$

This history of struggle against slavery is still too little-known today and hardly discussed in the public space, while the descendants of enslaved populations live in precarious conditions due to continuous historical marginalization and stigmatization. Due to this ongoing economic marginalization, the new generations are vulnerable to further exploitation, such as for girls to work as "young maids" in Kayes to support their family. In such cases, new forms of servitude strongly overlap with the legacies of historical slavery. ${ }^{22}$

19 Carolyn Norris, "Final Evaluation of Civil Society Challenge Fund project: Challenging Descent-based Slavery in West Africa," Anti-slavery International, 21 May 2012 http:// www.antislavery.org/wp-content/uploads/2016/12/descent_based_slavery_evaluation-2O 12.pdf, accessed 10 November 2019.

20 Bruce S. Hall, A History of Race in Muslim West Africa (1600-1960) (Cambridge, Eng.: Cambridge University Press, 2011); Baz Lecocq, "The Bellah Question: Slave Emancipation, Race, and Social Categories in Late-Twentieth Century Northern Mali," Canadian Journal of African Studies, 39 (1) (2005): 42-68; Lotte Pelckmans, Travelling hierarchies: Moving in and out of slave status in a Central Malian Fulbe network (Leiden: African Studies collection, 34, 2011).

21 In Kayes, out of 43 cases presented to the criminal court since 2018, 21 cases of hate crimes related to descent-based slavery have been heard. https://maliactu.net/mali-cour-dassises -de-kayes-43-affaires-criminelles-au-role/, accessed 15 April 2019.

22 Marie Rodet, "Slavery: West Africa", in Encyclopedia of Women \& Islamic Cultures, General Editor Suad Joseph. First published online: 2016, http://dx.doi.org/10.1163/1872-5309_ewic _COM_oo2O38, accessed 12 December 2019. 
By presenting historic accounts of resistance against slavery in the first half of the twentieth century in Kayes, the film helps explore how such historical material can be mobilized to empower those communities but also to fight against contemporary forms of exploitation, including modern slavery.

A first screening tour was organized from 11 to 16 February 2017 in Kayes and in nine of the villages where the film had been shot. More than 6,ooo people in total attended those screenings; a majority were children and adult women. ${ }^{23}$ Those screenings most often took place on the main public square of the village in open air or, in some cases, in the local school. Being the historical subjects of a film that is screened publicly on a big screen had a catalyst factor as it put for the very first time those communities under the spotlight. It further encouraged some in the audience to bring their own testimony of what they knew about slavery and what their ancestors may have experienced. In Bouillagui for example, a man from the public explained that his grandmother told him how slave merchants would prick spines in slaves' feet at night to prevent them from running away. Another young man explained how people from outside the village would call him a slave because he was from Bouillagui and how he had once started a fight because of this. ${ }^{24}$ Others realized through the film how much they had been in denial of this history and experienced mixed feelings of shame and pride at the same time when watching the film. ${ }^{25}$

Those encounters have further informed my research, as they prompted new testimonies that I was not aware of, and further helped to sharpen my understanding of the complex legacies of slavery in the region. The best example is probably linked to the title of the documentary: The Diambourou. I had chosen this term as it came up regularly in the conversations and interviews that I did in Kayes in 2009-2010, when people would designate communities formed by freed slaves following the abolition of slavery. There was even a village that had been called Diambouroubougou, the "village of the Diambourou," but whose name had been later changed into Banzana by the inhabitants themselves. It is really with the screenings and the reactions of the audiences in Kayes that I realized the full significance of this word. One woman in the audience asked me during the Q\&A whether I really knew what it exactly meant, to which I responded it was synonymous with the Libertés, the freed slaves who settled in Kayes and the neighboring villages. ${ }^{26}$ The woman then explained to me that the

CAN/Kadidia Sidibé. "ESClaVAge INTERne—KAYES 2017". Report on the February 2017 Diambourou. April 2017.

24 Debate with the audience following screening in Bouillagui, 15/02/2017.

25 Debate with the audience following screening in Kayes-Liberté, 12/02/2017.

26 Debate with the audience following screening in Kayes Liberté, 12/o2/2017. 
term could be understood on several levels, depending on the situation and the locality, but often in a derogatory way to designate someone who is not serious, who does not care and who refused any authority. It was also a term used to minimize the social status of someone by implying that this person is impure. Finally, the term was also used to call a girl a prostitute. ${ }^{27}$ She was thus quite surprised that I used the term as the title of my film and was wondering whether I was aware of those aspects. Indeed, at the time I chose the title of my film I was not aware of the use of Diambourou as a very derogatory term in certain localities.

In February 2018 I organized a second series of screenings in the schools of Kayes, in the Lycée Dougoukolo Konaré, and the secondary school Liberté A. More than two hundred pupils attended the film screening over a total of five projections. For those screenings I decided to start the presentation by asking the pupils whether they know the term Diambourou and how they would define it. The question was always greeted by bursts of laugher and confusion whether they could tell freely how they understood this derogatory term. I would then tell them that I would like to know following the film whether they would still define and use the term in the same way. Following the film screening, the majority of the pupils would then say that they now understood that the term actually designated "People who fought to obtain their freedom," "People who have been forcedly enslaved but who gained their freedom" or "Emancipated slaves." ${ }^{28}$

What became even more significant with those screenings was the emotional power the film contained. As explained in the first section, I had attempted to address the emotional aspect in the film through music in particular. By collecting testimonies of this history of violence from elderly people I had not anticipated the emotional impact those testimonies would have on the Malian audiences. For the screening tours, the parts of the film which were in French and in other languages not spoken by the audience, were translated live by my research assistant Mamadou Sène Cissé. The histories told in the film were of course not neutral histories and shared emotion-laden experiences in the mother tongues of the audience, so that the audience could feel

27 On the issue of honour and the slaves having no shame, especially women being shameless, see Martin A. Klein, "The Concept of Honour and the Persistence of Servility in the Western Soudan," Cahiers d'études africaines [Online], 179-180 | 2005, first published on 1 January 2007, http://journals.openedition.org/etudesafricaines/15018, accessed 3 May 2019.

28 Analysis based on 88 feedback questionnaires filled out by pupils of the Lycée Doukolo Konaré following screenings between the 19th and 23rd of February 2017. My own translation from French to English. 
and care deeply about those events and people, emotions which could not have been rendered in the same way through an academic written publication. ${ }^{29}$ When editing the film, I had hoped the documentary was able to tap into social emotions, or as Nichols puts it: to question "our very subjectivity in the social arena." ${ }^{30}$ But it is really through those screenings in Kayes that I realized the extent of the power of film to impact on and raise awareness among the younger generations. Some of the reactions by the pupils of the Lycée clearly show how emotions played a crucial role in their perception of the film's significance:

Pupil 1: "I want to know more about the history of slavery even if it makes me cry from the start to the end."

Pupil 2: "If I had the means, I would help you to inform the public more and fight against slavery."

Pupil 3: "Through those stories, we can get inspired about how to fight against slavery ... This film allows me to know more about the history of my country, it also gives me ideas and courage to fight just like [the slaves] fought for their freedom."

Pupil 4: "This film changes our vision of the enslaved populations, as it shows the injustice done to them, that slavery is not good and that it has to be stopped". ${ }^{31}$

The reactions of the pupils also show that the film was a powerful tool to capitalize on historical resistance against slavery in Kayes to raise awareness among young generations about the importance of fighting against all forms of discrimination and exploitation, including modern slavery. The use of the film for fighting against discrimination, descent-based slavery and modern slavery has even taken a new dimension from the moment I put it online in December 2017; it caught the attention of anti-slavery activists from the Soninke Diaspora in Paris, whereas the Kayes region experienced a dramatic increase of the number of victims of severe exactions due to descent-based slavery. This

29 Robert A. Rosenstone, History on Film/Film on History (Harlow: Pearson. Longman, 2006); David MacDougall, Transcultural Cinema (Princeton, NJ: Princeton University Press, 1998); Eric K. Hahonou, "Film et texte, émotion et cognition" Esclavages \& Post-esclavages [Online], 1, 20 November 2019, http://journals.openedition.org/slaveries/431, accessed 25 November 2019.

30 Bill Nichols, Representing Reality: Issues and Concepts in Documentary (Bloomington: Indiana University Press, 1991), 194.

$31 \quad$ Feedback questionnaires. Lycée Doukolo Konaré, 19-23 February 2018. 
heightened violence was partly a reaction to the rise of Soninke anti-slavery activism led from the Diaspora and the active refusal by people in Kayes to be called "slave" and be treated as second-class citizen. ${ }^{32}$

\section{Epilogue: Action Research through Film}

Since the 2nd of December 2017, The Diambourou is on free access on the web. It has generated 4,640 views in two years. ${ }^{33}$ The views especially increased following my liaising in 2018 with the Anti-slavery activist group Ganbanaaxun of the Soninke Diaspora in Paris who regularly reposted the link on their Facebook page. ${ }^{34}$ Following a joint Diambourou screening event Ganbanaaxun Fedde, SOAS, CIRESC in Paris on 26 October 2019, the video was viewed online 738 times within 24 hours. The screening and the following conference/debate were crucial for the Ganbanaaxun activists as it offered them a unique platform at EHESS, a prestigious university in France and thus intellectual legitimacy in their transnational fight against slavery in West Africa. ${ }^{35}$ In this context, the film has allowed viewers to make important bridges between historical resistance and contemporary anti-slavery activism. It has also reinforced the legitimacy of and the cohesion in today's activism against slavery and its legacies in West Africa, whereas the dominant ideology has actively erased historical resistance against slavery from the public memory. ${ }^{36}$

The heightened violence against victims of descent-based slavery in the Kayes region and my connection with the Ganbanaaxun fedde have reminded me that historic fighting for equality, even when successful such as in the case of the Diambourou in Kayes, can never be completely secured, especially when the dominant hegemonic ideology has continuously worked on weak-

32 Since October 2018, more than 1,0oo people have been officially displaced in the Kayes region (Mali) to escape violence linked to internal slavery and its legacies: more than 1,500 refugees are currently hosted in Mambiri, Diéma and Konobougou in the Kayes region.

33 Vimeo Analytics. Accessed 10/o1/2020.

34 Ganbanaaxun Fedde Armepes Facebook page: https://www.facebook.com/ARMEPES/, accessed 10 January 2020.

35 Whatsapp video testimony by Moumy Traoré. 4 November 2019. Soninkidées j' ose, "Après le visionnage du film les Diambourou, quell impact pour notre militantisme Ganbanaaxu fedde," https://soninkideesjose.wordpress.com/2019/11/o1/\%e2\%9c\%85apres-le -visionnage-du-film-les-diambourou-quel-impact-pour-notre-militantisme-ganbanaaxu -fedde/, accessed o1 November 2019 .

36 Marie Rodet, "Mémoires de l' esclavage dans la région de Kayes: Histoire d'une disparition," Cahiers d'Études Africaines 197(2010): 263-291. 
ening such social movements by making sure that those struggles were being erased from public memory and history. Each new generation is thus impeded from capitalising on previous struggles and has almost to start from scratch to raise awareness and fight for equality. This, at a time when security issues, terrorism and poor governance in the Sahel already create conditions in which exploitation and slavery can thrive easily again. Screening my film in such context has questioned my understanding of slavery and post-slavery in Kayes. It has pushed me to start re-examining carefully under which socio, economic and political circumstances such struggles may occur, how and why despite their regular occurrences in the past 100 years, they have been largely denied and made invisible, thus preventing any government's anticipation, efficient management and possible prevention until today. For example, the struggle around terms used is also fully part of this specific history of slavery denial in Kayes: at the local level, the term used to designate certain social categories is unambiguously "slave," but at the official level slavery-like practices are being designated as "custom." Not using the term slavery here helped delegitimize the work of anti-slavery activists fighting against those practices. During the film screening in Paris with the Ganbanaaxun fedde activists, a Mauritanian member of parliament representing the Mauritanians of the diaspora in France who was attending the debate categorically objected to the use of the word "slavery" and used the term "custom" ("ladda" in Soninke) or discrimination instead to designate those practices. He clearly attempted to delegitimate the message of anti-slavery activists in the audience to deny the reality of physical, social and symbolic violence perpetuated against the populations with ascribed "slave status" among the Soninke. The online attacks by Malians against the film and the implied denial have also been quite fierce. The performative power of film encourages audiences to reflect on the significance of the terms used and to rethink how their use of language may question social hierarchies or help to maintain social hierarchies. ${ }^{37}$

The power of putting history on film in such context is potentially demultiplied, as it helps free the word in communities where some social realities are still partly unutterable, denied and silenced. ${ }^{38}$ Moving images can tell and/or show historical and contemporary social hierarchies and violence that

37 Eric K. Hahonou, "Film et texte, émotion et cognition" Esclavages \& Post-esclavages [Online], 1 | 2019, published 20 November 2019. http://journals.openedition.org/slaveries/ 431, accessed 25 November 2019.

38 Patrick Deshayes, "Des écritures cinématographiques d' avenir en sciences humaines et sociales", in Marina Rougeon and Patrick Deshayes, eds. Montrer les esclavages et leurs héritages. Films et regards de chercheurs (Lyon: PUL, 2016), 24-49. 
cannot otherwise be expressed and put in word in the public sphere beyond the family circles. But research action through film has also its own limits, both practically and methodologically. Yet, it was clear from the teachers in the Lycée and schools in Kayes that the documentary was not enough and that tangible teaching material was needed to reach many more pupils. Indeed, organising screenings is much more demanding in terms of logistics, and schools in Kayes are in no way equipped to organise their own screenings. They have no equipment, not even electricity in the classrooms in some cases. I am thus currently working on co-producing a graphic novel on historical resistance against slavery in Kayes with the village of Bouillagui which was founded following a rebellion against slavery in the 1910s. If the use of such mediums can certainly be transformative, participatory research and co-production pose political and ethical challenges on their own. ${ }^{39}$

\section{Works Cited}

Araujo, Ana Lucia. "The Diambourou: slavery and emancipation in Kayes-Mali [DVD]," Slavery \& Abolition, 36:2 (2015), 406-408.

Cavarero, Adriana. Relating Narratives: Storytelling and Selfhood (London and New York: Routledge, 2000).

Hahonou, Eric K. "Film et texte, émotion et cognition" Esclavages \& Post-esclavages [Online], 1 (2019), published 2o November 2019. http://journals.openedition.org/ slaveries/431, accessed 25 November 2019.

Hahonou Eric K. \& Lecocq, Baz. "Introduction: Exploring Post-Slavery in Contemporary Africa." International Journal of African Historical Studies 48(2) (2015), 181-192.

Hahonou, Eric K. \& Pelckmans, Lotte. "West African Antislavery Movements: Citizenship Struggles and the Legacies of Slavery." Stichproben-Wiener Zeitschrift für kritische Afrikastudien 20 (2011), 141-162.

Deshayes, Patrick. "Des écritures cinématographiques d' avenir en sciences humaines et sociales." In Montrer les esclavages et leurs héritages. Filmsetregards de chercheurs, eds. Marina Rougeon and Patrick Deshayes (Lyon: PUL, 2016), 24-49.

Hall, Bruce S. A History of Race in Muslim West Africa (160o-1960) (Cambridge: Cambridge University Press, 2011)

Herskovits, Melville J. The Myth of the Negro Past (New York: Harper Brothers, 1941).

Hoechner, Hannah. "Participatory Filmmaking with Qur'anic Students in Kano, Nig-

39 Hannah Hoechner, "Participatory Filmmaking with Qur'anic Students in Kano, Nigeria: 'Speak good about us or keep quiet!'” International Journal of Social Research Methodology, 18:6 (2015): 635-649, DOI: 10.108o/13645579.2014.929877, accessed 1o November 2019. 
eria: 'Speak good about us or keep quiet!'” International Journal of Social Research Methodology, 18(6) (2015), 635-649.

Klein, Martin A. "Studying the History of those Who Would Rather Forget: Oral History and the Experience of Slavery." History in Africa 16 (1989), 209-217.

Martin, Klein A. "The Concept of Honour and the Persistence of Servility in the Western Soudan," Cahiers d'études africaines [Online], 179-180 (2005), first published on 1 January 2007, http://journals.openedition.org/etudesafricaines/15018, accessed 3 May 2019.

Lawrance, Benjamin N. “'To Know Where You Come from; That Is Divine': Three New Documentary Films on the African Slave Experience," Slavery \& Abolition, 36(4) (2015), 738-746.

Lecocq, Baz. "The Bellah Question: Slave Emancipation, Race, and Social Categories in Late-Twentieth Century Northern Mali," Canadian Journal of African Studies, 39(1) (2005), 42-68.

MacDougall, David. Transcultural Cinema (Princeton, NJ: Princeton University Press, 1998)

Maitilasso, Annalisa. “'Prêts à partir'. Histoires de mobilité transnationale en temps de crise: le cas malien" (Sociology, EHEss, 2017).

Nichols, Bill. Representing Reality: Issues and Concepts in Documentary (Bloomington: Indiana University Press, 1991).

Pelckmans, Lotte. Travelling hierarchies: Moving in and out of slave status in a Central Malian Fulbe network (Leiden: African Studies collection, 34, 2011).

Rodet, Marie. "Mémoires de l' esclavage dans la région de Kayes: Histoire d'une disparition." Cahiers d'Études Africaines 197 (2010), 263-291.

Rodet, Marie. "Listening to the History of Those Who Don't Forget." History in Africa 40 (2013), 27-29.

Rodet, Marie. "Escaping slavery and building diasporic communities in French Soudan and Senegal, ca. 1880-1940," International Journal of African Historical Studies 48(2) (2015), 209-237.

Rodet, Marie. "Slavery: West Africa." In Encyclopedia of Women \& Islamic Cultures, ed. Suad Joseph (2016) http://dx.doi.org/10.1163/1872-5309_ewic_COM_oo2O38, accessed 12 December 2016.

Rossi, Benedetta. "Without History? Interrogating Slave Memories in Ader (Niger)." In African Voices on Slavery and the Slave Trade, eds. Alice Bellagamba, Sandra Greene, Martin A. Klein (Cambridge and New York: CUP, 2013), 536-554.

Rougeon, Marina. "Introduction: Des films pour la recherche sur les esclavages et leurs héritages", In Montrer les esclavages et leurs héritages. Films et regards de chercheur, eds. Marina Rougeon and Patrick Deshayes, (Lyon: PUL, 2016), 5-24.

Rosenstone, Robert A. History on Film/Film on History (Harlow: Pearson. Longman, 2006). 